\title{
Testing Some Pedo-Transfer Functions (PTFs) in Apulia Region. Evaluation on the Basis of Soil Particle Size Distribution and Organic Matter Content for Estimating Field Capacity and Wilting Point
}

\author{
Floriano Buccigrossi, Angelo Caliandro, Pietro Rubino*, Mario Alberto Mastro \\ Dipartimento di Scienze delle Produzioni Vegetali, Università degli Studi di Bari \\ Via G. Amendola 165/A, 70126 Bari, Italy
}

Received: 16 May 2010. Accepted: 7 September 2010.

\begin{abstract}
The knowledge of soil water retention vs. soil water matric potential is applied to study irrigation and drainage scheduling, soil water storage capacity (plant available water), solute movement, plant growth and water stress. To measure field capacity and wilting point is expensive, laborious and is time consuming, so, frequently, matemathic models, called pedo-transfer functions (PTFs) are utilized to estimate field capacity and wilting point through physical-chemical soil characteristics. Six PTFs have been evaluated (Gupta and Larson, 1979; Rawls et al., 1982; De Jong et al., 1983; Rawls and Brakensiek, 1985; Saxton et al., 1986; Vereecken et al., 1989) by comparing measured soil moisture values with estimated ones at soil water matric potential of -33 and $-1500 \mathrm{kPa}$. Soil samples were collected (361) from 185 pedons of Apulian Region (Southern Italy).

Accuracy of the soil moisture predictions is quantified with Root Mean Square Deviation (RMSD) between estimated and measured water retention values.

In Apulia Region the tested PTFs give different results on soils grouped on the basis of textural composition and organic matter (O.M.) content both at the Field Capacity (FC) and Wilting Point (WP).

At the FC, Gupta and Larson model has given the best performance in Clayey (C), Sandy clay loam (SaCL), Sandy loam (SaL) and Silty (Si) soil, in loamy and tendency silty soils with O.M. content less than $1.9 \%$ and in tendency sandy soils with O.M. content less than $1.5 \%$ and greater than $2 \%$; the Rawls model in Silty clay (SiC) and Silty loam (SiL) soils, in tendency clayey soils with O.M. less than $2.3 \%$ and in loamy and tendency silty soils with O.M. greater than 1.9\%; the Rawls and Brakensiek model in tendency sandy soils with O.M. content between 1.5 and $2 \%$; the Saxton model in Silty clay loam (SiCL), Loamy sand (LSa) soils and in tendency clayey soils with O.M. content greater than $2.3 \%$ and the Vereecken model in Sandy clay (SaC), Loamy (L), Clay loam (CL) and Sandy (Sa) soils. At the WP, the Gupta and Larson model has resulted the best in SiL, Si soils and, in general, in loamy and tendency silty and in tendency sandy soils with O.M. content greater than $1.9 \%$ and $2 \%$, respectively; the Rawls model in Loamy soils and in loamy and tendency silty soils with O.M. between 1.0 and $1.9 \%$; the De Jong model in $\mathrm{C}$ soils; the Rawls and Brakensiek model in $\mathrm{SiC}, \mathrm{SaC}, \mathrm{CL}, \mathrm{SiCL}, \mathrm{SaCL}$ soils and generally in tendency clayey soils with whatever O.M. content and in tendency sandy soils with O.M. content between 0.8 and $2 \%$; the Saxton model in loamy and tendency silty soils with O.M. content less than $1 \%$ and in tendency sandy soils with O.M. less than $0.8 \%$; the Vereecken model in SaL, Sa and LSa soils.
\end{abstract}

Key-words: field capacity and wilting point, pedotransfer functions, soil water retention models.

\section{Introduction}

Field capacity and wilting point can be estimated with the application of pedotransfer functions (Pedo-Transfer Function - PTF - expression used by Bouma in 1989) through physical-chemical characteristics of pedological horizons (Rawls et al., 1991), which affect soil wa- ter retention, such as sand, silt, clay content (particle size distribution), organic matter or organic carbon and total $\mathrm{CaCO}_{3}$ content, soil bulk density, aggregate size distribution, free iron oxide (Jamison and Kroth, 1958; Prebble and Stirk, 1959; Salter and Williams, 1965a, b; Petersen et al., 1968; Wösten and van Genuchten, 1988). These last parameters, comparing with labora-

\footnotetext{
* Corresponding Author: Tel. +39 080 5443032; Fax +39080 5442976. E-mail address: pietro.rubino@agr.uniba.it
} 
tory measures of field capacity and wilting point, are easily and quickly determined, and at low cost.

In a previous work carried out by Buccigrossi et al., (still in press) the applicability of six literature' PTFs (Gupta and Larson, 1979, b; Rawls et al., 1982; De Jong et al., 1983; Rawls and Brakensiek, 1985; Saxton et al., 1986; Vereecken et al., 1989) has been evaluated in soils of Apulia Region (361 soil samples deriving from 185 pedons) regardless of their particle size distribution and organic matter content. The best accuracy of soil moisture predictions has been obtained: at the Field Capacity $(-33 \mathrm{kPa})$ with Rawls PTF that shows the lowest values of WSEE (weighted standard error of estimate), MD (mean deviation) and RMSD (root mean squared deviation) (0.044, -0.007 e $0.059 \mathrm{~m}^{3}$ water $\mathrm{m}^{-3}$ soil, respectively); at the Wilting Point $(-1500 \mathrm{kPa})$ with Rawls and Brakensiek model with values of WSEE, MD and RMSD of $0.034,-0.016$ and $0.046 \mathrm{~m}^{3}$ water $\mathrm{m}^{-3}$ soil, respectively.

For further investigations, the applicability of the six PTFs to soils of Apulian Region grouped in textural classes and, within the three great textural grouping (tendency clayey soils; loamy and tendency silty soils; tendency sandy soils) in classes of organic matter content, has been evaluated.

\section{Materials and methods}

To evaluate the applicability of the six PTFs to the groupings of soils of Apulian Region, data sets of measured water content at field capacity and at wilting point of 361 soil samples collected from 185 pedological profiles on Apulian territory (Fig. 1) have been used.

Before making physical-chemical laboratory analysis, soil samples have been air-dried and 2 mm mesh sieved.

In laboratory, on sieved soil samples, organic matter content (\% OM) (Walkley-Black method), particle size fraction, according with USDA textural classification (U.S. Dept. Agric., 1951) \{sand $[2 \geq \operatorname{diameter}(\mathrm{d}) \geq 0.05 \mathrm{~mm}$ ], silt $(0.05 \geq \mathrm{d} \geq 0.002 \mathrm{~mm})$ and clay $(\mathrm{d} \leq 0.002 \mathrm{~mm})$ (pipette method and determination of coarse sand with humid sieved)\}, water content ( $\%$ of soil dry weight) at $-33 \mathrm{kPa}$ [Field Capacity (FC)] and $-1500 \mathrm{kPa}$ [Wilting Point (WP)], with porous plates in Richards pressure chambers (Richards e

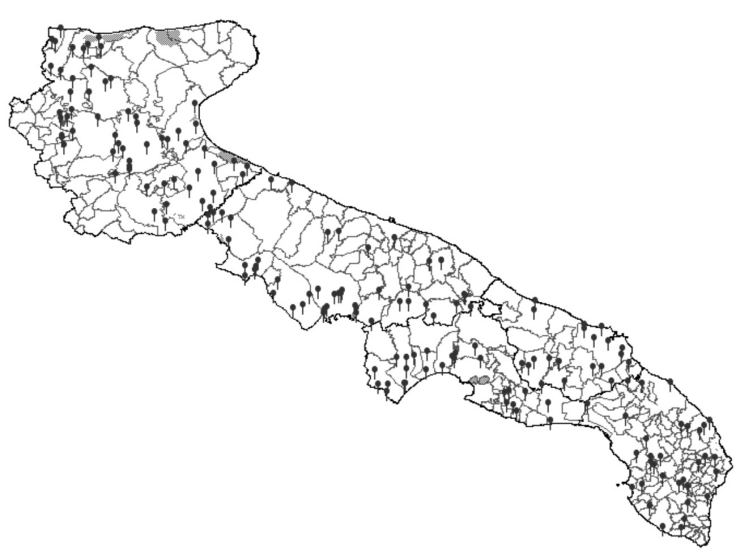

Figure 1. Localization of the 185 pedological profiles on Apulian territory.

Weaver, 1947; Richards, 1949), have been measured.

The soils have been grouped in 12 textural classes according to USDA textural classification (Tab. 1), in 12 classes of organic matter content, 4 classes of organic matter content for each of the 3 great textural groupings, (Sequi and De Nobili, 2000) for a total of 24 soil groupings. On the basis of organic matter content, the great textural groupings are (Tab. 2):

a) tendency clayey soils, including Clayey (C), Silty clay (SiC), Clay loam (CL) and Silty clay loam (SiCL) soils;

b) loamy and tendency silty soils, including Loamy (L), Silty loam (SiL), Sandy clay loam $(\mathrm{SaCL})$, Sandy clay $(\mathrm{SaC})$ and Silty $(\mathrm{Si})$ soils;

c) tendency sandy soils, including Sandy (Sa), Sandy loam (SaL) and Loamy sand (LSa) soils (Sequi and De Nobili, 1.c.).

Soil bulk density $\left(\rho_{\mathrm{b}}\right)$ can be estimated through specific models and/or PTFs (Curtis and Post, 1964; Saini, 1966; Heinonen, 1977; Gupta and Larson, 1979 a; Alexander, 1980; Rawls and Brakensiek, 1989; Leonavičiuté, 2000); in this case, the following equation (Adams, 1973; Rawls, 1982) has been applied:

$$
\begin{aligned}
& 100
\end{aligned}
$$

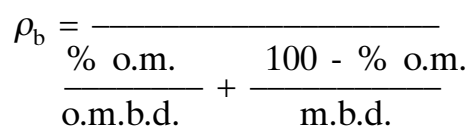

where:

o.m.: organic matter;

o.m.b.d.: organic matter bulk density, in average equal to $0.224 \mathrm{~g} \cdot \mathrm{cm}^{-3}$; 
Table 1. Textural classes (USDA textural classification) and relative number of soil samples for each class.

\begin{tabular}{|c|c|c|c|c|c|}
\hline \multirow{2}{*}{\multicolumn{2}{|c|}{$\begin{array}{l}\text { Textural classes } \\
\text { (USDA classification) }\end{array}$}} & \multicolumn{3}{|c|}{$\begin{array}{l}\text { Textural ranges } \\
(\%)\end{array}$} & \multirow{2}{*}{$\begin{array}{l}\text { Soil Samples } \\
\\
\left(\mathrm{n}^{\circ}\right)\end{array}$} \\
\hline & & $\begin{array}{c}\text { Sand } \\
(2 \geq \mathrm{d} \geq 0.05 \mathrm{~mm})\end{array}$ & $\begin{array}{c}\text { Silt } \\
(0.05 \geq \mathrm{d} \geq 0.002 \mathrm{~mm})\end{array}$ & $\begin{array}{c}\text { Clay } \\
(\mathrm{d} \geq 0.002 \mathrm{~mm})\end{array}$ & \\
\hline Clayey & $\mathrm{C}$ & $0-47$ & $0-40$ & $40-100$ & 35 \\
\hline Silty clay & $\mathrm{SiC}$ & $0-20$ & $40-60$ & $40-60$ & 21 \\
\hline Sandy clay & $\mathrm{SaC}$ & $45-65$ & $0-20$ & $35-55$ & 5 \\
\hline Loamy & $\mathrm{L}$ & $20-52$ & $30-50$ & $7-30$ & 66 \\
\hline Clay loam & $\mathrm{CL}$ & $20-47$ & $15-50$ & $27-40$ & 45 \\
\hline Silty clay loam & $\mathrm{SiCL}$ & $0-20$ & $40-70$ & $30-40$ & 18 \\
\hline Sandy clay loam & $\mathrm{SaCL}$ & $45-80$ & $0-30$ & $20-35$ & 29 \\
\hline Silty loam & $\mathrm{SiL}$ & $0-50$ & $50-90$ & $0-30$ & 82 \\
\hline Sandy loam & $\mathrm{SaL}$ & $45-85$ & $0-50$ & $0-20$ & 48 \\
\hline Silty & $\mathrm{Si}$ & $0-20$ & $80-100$ & $0-10$ & 1 \\
\hline Sandy & $\mathrm{Sa}$ & $85-100$ & $0-15$ & $0-10$ & 2 \\
\hline Loamy sand & LSa & $70-90$ & $0-30$ & $0-15$ & 9 \\
\hline
\end{tabular}

Table 2. Soils grouped in classes of organic matter content in the three great textural grouping and number of soil samples for each class.

\begin{tabular}{|c|c|c|c|c|c|}
\hline $\begin{array}{l}\text { Textural } \\
\text { grouping }\end{array}$ & $\begin{array}{c}\text { Soils } \\
\text { samples } \\
\left(\mathrm{n}^{\circ}\right)\end{array}$ & $\begin{array}{l}\text { Textural classes } \\
\text { included }\end{array}$ & $\begin{array}{c}\text { Organic matter } \\
\text { content }\end{array}$ & $\% \mathrm{OM}$ & $\begin{array}{c}\text { Soil } \\
\text { samples } \\
\left(\mathrm{n}^{\circ}\right)\end{array}$ \\
\hline $\begin{array}{l}\text { tendency } \\
\text { clayey soils }\end{array}$ & 119 & $\begin{array}{l}\text { Clayey }(\mathrm{C}) \\
\text { Silty clay }(\mathrm{SiC}) \\
\text { Clay loam }(\mathrm{CL}) \\
\text { Silty clay loam }(\mathrm{SiCL})\end{array}$ & $\begin{array}{l}\text { very low } \\
\text { low } \\
\text { medium } \\
\text { high }\end{array}$ & $\begin{array}{c}<1,2 \\
1,2-2,3 \\
2,3-3,0 \\
>3,0\end{array}$ & $\begin{array}{r}38 \\
69 \\
8 \\
4\end{array}$ \\
\hline $\begin{array}{l}\text { loamy and } \\
\text { tendency silty } \\
\text { soils }\end{array}$ & 183 & $\begin{array}{l}\text { Loam (L) } \\
\text { Silty loam (SiL) } \\
\text { Sandy clay loam (SaCL) } \\
\text { Sandy clay (SaC) } \\
\text { Silty (Si) }\end{array}$ & $\begin{array}{l}\text { very low } \\
\text { low } \\
\text { medium } \\
\text { high }\end{array}$ & $\begin{array}{c}<1,0 \\
1,0-1,9 \\
1,9-2,5 \\
>2,5\end{array}$ & $\begin{array}{l}30 \\
70 \\
43 \\
40\end{array}$ \\
\hline $\begin{array}{l}\text { tendency } \\
\text { sandy soils }\end{array}$ & 59 & $\begin{array}{l}\text { Sandy (Sa) } \\
\text { Sandy loam (SaL) } \\
\text { Loamy sand (LSa) }\end{array}$ & $\begin{array}{l}\text { very low } \\
\text { low } \\
\text { medium } \\
\text { high }\end{array}$ & $\begin{array}{c}<0,8 \\
0,8-1,5 \\
1,5-2,0 \\
>2,0\end{array}$ & $\begin{array}{r}19 \\
24 \\
6 \\
10\end{array}$ \\
\hline
\end{tabular}

m.b.d.: mineral bulk density, graphically obtained through a mineral density map based on sand and clay percentages (Davis, 1973).

The computation of the bulk density through organic matter and mineral bulk density rather than measuring it in the field has been preferred, because its value is very changeable with the time, especially in clay or clay- silty soil and when the field is being cropped. Owing to the field experience of the authors, the clay- silty soil bulk density during the crop season varies as average of the cultivated layers $(0$ to $0.50 \mathrm{~m})$ from 1.2 to $1.6 \mathrm{~g} / \mathrm{cm} 3$. Therefore, in these con- ditions one can not know which value should consider.

This uncertainty is the reason which influenced the choice of the authors; using the formula found in literature and reported in this paper is equivalent to consider a standard method to which to refer.

\section{Applied pedo-transfer functions}

Many papers on this subject are reported in literature and most of them refers to undisturbed soil cores collected with the auger. In the mat- 


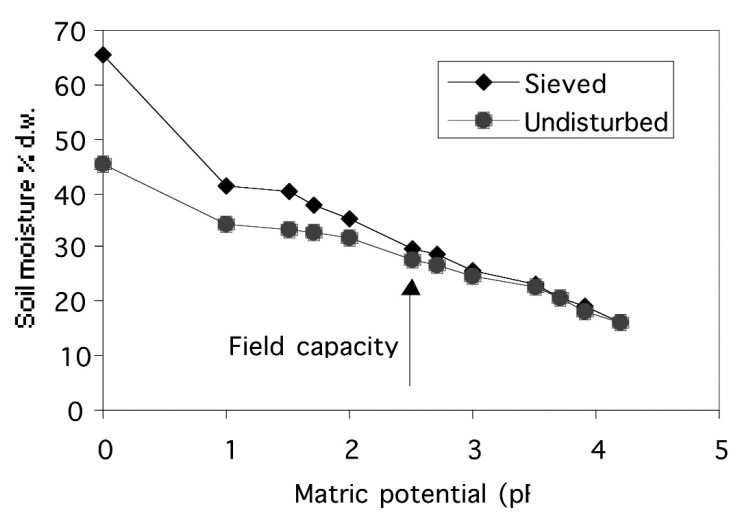

Figure 2. Soil moisture values (\% of dry weight ) vs. matric potential $(\mathrm{pF})$ of sieved and undisturbed soil samples.

ter, the authors carried out on a clay silty soil ( clay $=25 \%$; silt $=35 \%$; sand $=40 \%$ ) a field experiment to study the differences in soil moisture determined at different potentials among undisturbed and sieved soil samples. The data are reported in the Figure 2, from which you can easily see that from Field Capacity $(\mathrm{pF}=$
$2.5=-33 \mathrm{KPa})$ to Wilting Point $(\mathrm{pF}=4.2=$ $-1500 \mathrm{KPa}$ ) there is no significant difference between undisturbed and sieved soil moisture. Above Field Capacity the differences among the two series of soil moisture values become more and more higher up to saturation $(\mathrm{pf}=0)$.

For these reasons, the authors decided to carry out this study on sieved samples and they believe that the results obtained can be considered valid and applicable to other conditions and field studies in the range between Wilting Point and Field Capacity.

The PTFs studied and applied to estimate the volumetric water content $\left(\theta_{\text {est }}\right)$ at -33 and $-1500 \mathrm{kPa}$ matric potentials, are: Gupta and Larson, 1979 (model I); Rawls et al., 1982 (model II); De Jong et al., 1983 (model III); Rawls and Brakensiek, 1985 (model IV); Saxton et al., 1986 (model V); Vereecken et al., 1989 (model VI).

The algorithms, the equations of the parameters and the constants of each applied PTF are reported in Tables 3 and 4.

Table 3. Algorithms of the six applied PTFs.

\begin{tabular}{|c|c|}
\hline PTF & Algorithm \\
\hline $\begin{array}{l}\text { Model I } \\
\text { (Gupta \& Larson, 1979) }\end{array}$ & $\theta_{\mathrm{st}}=(\mathrm{a} \cdot \mathrm{S})+(\mathrm{b} \cdot \mathrm{L})+(\mathrm{c} \cdot \mathrm{A})+(\mathrm{d} \cdot \mathrm{SO})+\left(\mathrm{e} \cdot \rho_{\mathrm{b}}\right)$ \\
\hline $\begin{array}{l}\text { Model II } \\
\text { (Rawls et al., 1982) }\end{array}$ & $\theta_{\mathrm{st}}=\mathrm{a}+(\mathrm{b} \cdot \mathrm{S})+(\mathrm{c} \cdot \mathrm{L})+(\mathrm{d} \cdot \mathrm{A})+(\mathrm{e} \cdot \mathrm{SO})-\left(\mathrm{f} \cdot \rho_{\mathrm{b}}\right)$ \\
\hline Model III & $\theta_{\mathrm{st}}=\left\{\mathrm{a}+\left[\mathrm{b}_{1}\left(\log \Psi_{P m}-\mathrm{t}\right)\right]\right\} \times \rho_{\mathrm{b}} / 100, \quad$ per $\Psi P m \leq 10^{\mathrm{t}}$ \\
\hline (De Jong et al., 1983) & $\underset{10^{\mathrm{t}}}{\theta_{\mathrm{st}}}=\left\{\mathrm{a}+\left[\mathrm{b} 2\left(\log \Psi_{P m}-\mathrm{t}\right)\right]\right\} \times \rho_{\mathrm{b}} / 100, \quad$ per $\Psi P m>$ \\
\hline $\begin{array}{l}\text { Model IV } \\
\text { (Rawls \& Brakensiek, 1985) }\end{array}$ & $\theta_{\mathrm{st}}=\theta_{\mathrm{r}}+\left(\theta_{\mathrm{s}}-\theta_{\mathrm{r}}\right)\left[\left(1+\left|\Psi_{P m} / h_{b}\right|^{\mathrm{n}}\right)\right]^{-\mathrm{m}}$ \\
\hline $\begin{array}{l}\text { Model V } \\
\text { (Saxton et al., 1986) }\end{array}$ & $\theta_{\mathrm{st}}=\left(\Psi_{P m} / A\right)^{1 / B}$ \\
\hline $\begin{array}{l}\text { Model VI } \\
\text { (Vereecken et al., 1989) }\end{array}$ & $\theta_{\mathrm{st}}=\theta_{\mathrm{r}}+\left(\theta_{\mathrm{s}}-\theta_{\mathrm{r}}\right)\left(1+\left|\alpha \Psi_{P m}\right|^{\mathrm{n}}\right)^{-1}$ \\
\hline
\end{tabular}

where:

$\theta_{\text {est }}:$ estimate of the volumetric water content;

YPm: matric potential (in bar for De Jong et al., 1983; in dm for Rawls and Brakensiek, 1985 and Vereecken et al., 1989; in KPa for Saxton et al., 1986);

$h_{b}$ : air entry potential;

$\lambda$ : pore size distribution index;

$\theta_{\mathrm{r}}:$ residual water content;

$\theta_{\mathrm{s}}$ : saturation water content; it is assumed to be equal to porosity $(\varnothing)$ which is:

$\emptyset=1-\left(\rho_{\mathrm{b}} / \rho_{\mathrm{d}}\right)(\%$ in volume $)$ where:

$\rho_{\mathrm{b}}$ : soil bulk density $\left(\mathrm{g} \cdot \mathrm{cm}^{-3}\right)$;

$\rho_{\mathrm{d}}$ : soil real density that, on average, is equal to $2.65 \mathrm{~g} \cdot \mathrm{cm}^{-3}$;

$\mathrm{Sa}, \mathrm{Si}, \mathrm{C}$ and OM: sand, silt, clay percentages (limits of diameter according to USDA textural classification) and organic matter content. 
Table 4. Equations of the parameters and constants of the six applied PTFs.

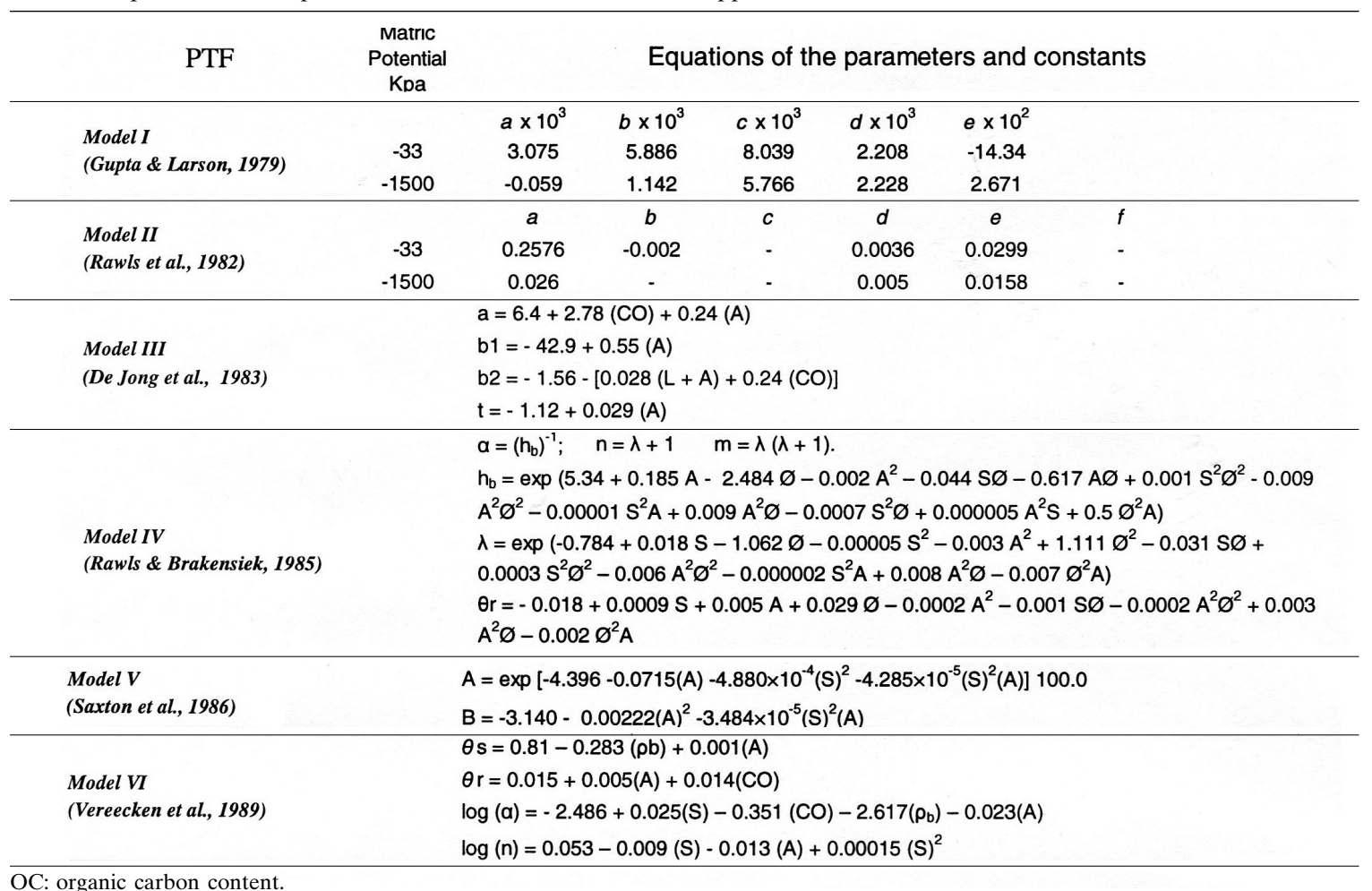

\section{Definition of evaluation criteria of the Pedo- Transfer functions applied to Apulian territory soils grouped on the basis of textural composi- tion and organic matter content}

For the soils grouped on the basis of textural composition and organic matter content, the following statistic errors and correlations of the differences among the values of water contents estimated by the six PTFs and those measured in laboratory (Wosten et al., 2001), have been calculated:

1. mean deviation (MD) or mean error (ME) among estimated and measured water retention values. MD is a positive or negative number according to whether the PTF overestimates or underestimates the water content, respectively;

2. root mean squared deviation (RMSD) or root mean square residual (RMSR) or root mean square error (RMSE);

3. determination coefficients $\left(\mathrm{R}^{2}\right)$ of the linear regressions among the values of water contents estimated with the six PTFs and measured in laboratory;

4. determination coefficients $\left(\mathrm{R}^{2}\right)$ of the linear regressions among the values of water contents estimated with the six PTFs and mea- sured, setting intercepts to zero when their values have not been statistically different from zero;

5. Prediction efficiency (P Ef) also known as Nash Sutcliffe index (Romano and Palladino, 2002).

$\operatorname{P~Ef~}(\%)=\left\{1-\left[\left(\theta_{\text {est }}-\theta_{\mathrm{d}}\right)^{2} /\left(\theta_{\mathrm{d}}-\theta_{m \mathrm{~d}}\right)^{2}\right]\right\} \xi 100$

where:

$\theta_{\mathrm{d}}$ : water content ( $\%$ in volume) measured in laboratory;

$\theta_{\text {est }}:$ water content ( $\%$ in volume) estimated with the PTF;

$\theta_{m \mathrm{~d}}:$ mean value of water content (\% in volume) measured in laboratory for a particular soil grouping.

Prediction efficiency is an evaluation PTF' index that ranged from $100 \%$ (it is a hypothetical case of an ideal PTF that estimates water content exactly equal to one determinated in laboratory) to $-\infty$ (when the soil grouping is so homogenous that the deviations of the moisture values from the mean value is equal to zero).

The analysis of variance has been performed 
with SAS software (SAS INSTITUTE INC.USA) with $P$ values equal to 0,05 and 0,01 . Then the protected SNK test has been performed for only significant parameters.

To understand the applicability of the six PTFs to the different soil types of the Apulian territory, grouped on the basis of textural composition and organic matter content, it has been investigated, for each PTF, the effect of the physical-chemical parameters on the magnitude of the statistical error, through the correlation among input parameters and the differences among soil moistures measured and estimated by the six PTFs $(\Delta \varnothing=$ error) (Tietje and Tapkenhinrichs, 1993; Cornelis et al., 2001; Ungaro and Calzolari, 2001).

In this way, applying a given PTF to estimate soil moisture at the FC or at the WP in a given soil grouping, a high correlation coefficient would point out a high degree of association between an input parameter and soil moisture error, that is, the considered PTF would be hardly suitable for that soil type.

On the contrary, a low correlation coefficient has a low degree of association between an input parameter and the differences among soil moistures measured and estimated $(\Delta \varnothing)$, that is, the considered PTF is suitable for the category of soil considered.

\subsection{Choice of the best PTF for each soil grouping}

In order to draw up the final score of the PTFs applied to estimate the soil moisture at
-33 and $-1500 \mathrm{KPa}$ matric potentials for the soils grouped on the basis of textural composition and organic matter content. On a preliminary step, a ranking has been drawn for each index: in this way the "partial" rankings have been obtained. Further on, for each PTF, the final ranking has been calculated by means of the partial rankings, putting at the first place the PTF with the mean nearest to one, i. e. the PTF with: MD and RMSD indexes nearest to zero, the greatest determination coefficients and prediction efficiency and straight line slope, when intercept throught zero was possible, nearest to one.

\section{Results and discussion}

The comparisons between estimated and measured soil moisture values, have permitted to select the best PTF for estimating soil moisture at the Field Capacity (FC) and Wilting Point (WP) of all Apulian soil groupings, having different textural composition and organic matter content.

The analysis of all evaluated PTF indexes show that the RMSD index alone provides excellent information on the PTF performances for a certain soil grouping; the ranking based on RMSD is equal to the final ranking obtained from all applied indexes: in Table 5 an example is reported. The same result has been obtained validating the PTFs on total data set independently from the textural composition and organic matter content (Buccigrossi et al., 2009).

Table 5. Statistical indexes values (with partial rankings) used for PTFs evaluation for estimating water retention at the Field Capacity in Clayey soils.

\begin{tabular}{|c|c|c|c|c|c|c|c|c|c|c|c|c|c|c|c|}
\hline \multicolumn{2}{|l|}{ PTF } & \multirow{3}{*}{$\begin{array}{c}\text { Intercept } \\
\text { (a) } \\
0,099 \\
-\end{array}$} & \multicolumn{2}{|c|}{$\begin{array}{l}\text { Straigh line } \\
\text { slope }\end{array}$} & \multicolumn{2}{|c|}{$\begin{array}{c}\text { Significance } \\
\operatorname{Pr}>|t|\end{array}$} & \multicolumn{2}{|c|}{$\mathrm{R}^{2}$} & \multicolumn{2}{|c|}{ MD } & \multicolumn{2}{|c|}{ RMSD } & \multicolumn{2}{|c|}{ P Ef } & \multirow{2}{*}{$\begin{array}{l}\text { final } \\
\text { ranking }\end{array}$} \\
\hline & & & (b) & ranking & (a) & (b) & value & ranking & $\mathrm{m}^{3} \cdot \mathrm{m}^{-3}$ & ranking & $\mathrm{m}^{3} \cdot \mathrm{m}^{-3}$ & ranking & $\%$ & ranking & \\
\hline $\begin{array}{c}\text { Gupta \& } \\
\text { Larson, } \\
1979\end{array}$ & $\begin{array}{l}\text { (1) } \\
\text { (2) }\end{array}$ & & $\begin{array}{l}0,785 \\
1,003\end{array}$ & $\begin{array}{l}- \\
1\end{array}$ & $\begin{array}{c}0,37 \\
-\end{array}$ & $\begin{array}{l}0,0027 \\
0,0001\end{array}$ & $\begin{array}{l}0,235 \\
0,965\end{array}$ & $\begin{array}{l}3 \\
3\end{array}$ & $\begin{array}{c}- \\
0.005\end{array}$ & 2 & 0,087 & 1 & 21,6 & 1 & 1 \\
\hline $\begin{array}{c}\text { Rawls et al., } \\
1982\end{array}$ & $\begin{array}{l}\text { (1) } \\
\text { (2) }\end{array}$ & $\begin{array}{c}0,105 \\
-\end{array}$ & $\begin{array}{c}0,79 \\
1,0354\end{array}$ & - & $\begin{array}{c}0,37 \\
-\end{array}$ & $\begin{array}{l}0,0046 \\
0,0001\end{array}$ & $\begin{array}{l}0,230 \\
0,964\end{array}$ & $\begin{array}{l}4 \\
4\end{array}$ & $\begin{array}{c}- \\
0.018\end{array}$ & 3 & 0,089 & 2 & 18,0 & 2 & 2 \\
\hline $\begin{array}{c}\text { Rawls \& } \\
\text { Brak., } 1985\end{array}$ & $\begin{array}{l}\text { (1) } \\
\text { (2) }\end{array}$ & $\begin{array}{c}-0,07 \\
-\end{array}$ & $\begin{array}{c}1,29 \\
1,1178\end{array}$ & $\begin{array}{l}- \\
5\end{array}$ & $\begin{array}{c}0,6 \\
-\end{array}$ & $\begin{array}{l}0,0003 \\
0,0001\end{array}$ & $\begin{array}{c}0,32 \\
0,970\end{array}$ & $\begin{array}{l}1 \\
1\end{array}$ & $\begin{array}{c}- \\
0.047\end{array}$ & 6 & 0,094 & 3 & 7,2 & 3 & 3 \\
\hline $\begin{array}{l}\text { Vereecken } \\
\text { et al., } 1989\end{array}$ & $\begin{array}{l}\text { (1) } \\
\text { (2) }\end{array}$ & $\begin{array}{c}-0,0827 \\
-\end{array}$ & $\begin{array}{c}1,299 \\
1,0996\end{array}$ & - & $\begin{array}{c}0,62 \\
-\end{array}$ & $\begin{array}{l}0,0026 \\
0,0001\end{array}$ & $\begin{array}{l}0,239 \\
0,966\end{array}$ & $\begin{array}{l}2 \\
2\end{array}$ & $\begin{array}{c}- \\
0.041\end{array}$ & 5 & 0,095 & 4 & 5,5 & 4 & 4 \\
\hline $\begin{array}{c}\text { De Jong et } \\
\text { al., } 1983\end{array}$ & $\begin{array}{l}\text { (1) } \\
\text { (2) }\end{array}$ & $\begin{array}{c}0,44 \\
-\end{array}$ & $\begin{array}{c}0,023 \\
1,0516\end{array}$ & $\begin{array}{l}- \\
3\end{array}$ & $\begin{array}{c}0,06 \\
-\end{array}$ & $\begin{array}{c}0,96 \\
0,0001\end{array}$ & $\begin{array}{c}0,000 \\
0,95\end{array}$ & $\begin{array}{l}6 \\
5\end{array}$ & $\begin{array}{c}- \\
0.025\end{array}$ & 4 & 0,106 & 5 & $-16,3$ & 5 & 5 \\
\hline $\begin{array}{l}\text { Saxton et } \\
\text { al., } 1986\end{array}$ & $\begin{array}{l}\text { (1) } \\
\text { (2) }\end{array}$ & $\begin{array}{c}0,332 \\
-\end{array}$ & $\begin{array}{c}0,2636 \\
-\end{array}$ & - & $\begin{array}{c}0,0001 \\
-\end{array}$ & $\begin{array}{c}0,0043 \\
-\end{array}$ & $\begin{array}{c}0,22 \\
-\end{array}$ & $\begin{array}{l}5 \\
6\end{array}$ & $\begin{array}{c}- \\
0.002\end{array}$ & 1 & 0,155 & 6 & $-150,3$ & 6 & 6 \\
\hline
\end{tabular}

(1) regression parameters among soil moisture values measured and estimated with the six PTFs with intercepts;

(2) regression parameters among soil moisture values measured and estimated with the six PTFs setting intercepts to zero. 
This result can be explained by taking into account that RMSD is a very restrictive index, more than the WSEE (weighted standard error of estimate) index (Buccigrossi et al., l.c.); moreover, it is intrinsically related to regression lines, in particular to the correlation coefficients between estimated and measured soil moistures (Kobayashi and Salam, 2000). The RMSD ranking is also equal to $\mathrm{P}$ Ef ranking.

Thus, considering that 48 data sets regarding 24 soil groupings (both at the FC and WP) have been analyzed, to make the results presentation easier, only RMSD values are reported.

\subsection{Soil grouped on the basis of textural com- position}

5.1.1 Soil moisture at the Field Capacity. For the 12 USDA textural classes the best estimated soil moisture values at the field capacity have been obtained with the model I, II, V and VI (table 6).

Model I shows the best results in Clayey (C), Sandy clay loam (SaCL), Sandy loam (SaL) and Silty (Si) soils. Nevertheless, in Clayey soils all compared PTFs have produced high RMSD values (all greater than $0.08 \mathrm{~m}^{3} \cdot \mathrm{m}^{-3}$ ) but not statistically different among them.

In Sandy loam soils the differences between estimated and measured soil moisture are lower than those observed in Clayey soils. In fact, the RMSD values are equal to $0.043 \mathrm{~m}^{3} \cdot \mathrm{m}^{-3}$ with the model I, to 0.051 and to $0.053 \mathrm{~m}^{3} \cdot \mathrm{m}^{-3}$ with the models II and VI, respectively, without significant differences among them.

Also in Sandy clay loam soils, very low difference values have been observed between estimated and measured soil moisture (0.037 $\mathrm{m}^{3} \cdot \mathrm{m}^{-3}$ ) with the model I, followed by VI and II models values, almost $4 \%$ and higher than the ones observed with the model I.

In the Sandy loam and Sandy clay loam soils, at the FC, the model $\mathrm{V}$ provides the highest differences between estimated and measured soil moistures.

In the Silty soils the lowest value of the RMSD index $\left(0.14 \mathrm{~m}^{3} \cdot \mathrm{m}^{-3}\right)$ has been obtained with model I, statistically different from the values obtained by the other applied PTFs. However, considering that only one soil sample belongs to this textural grouping, these results are not applicable to all Apulian silty soils.

For the Sandy clay (SaC), Loamy (L), Clay loam (CL) and Sandy (Sa) soils, the lowest RMSD values have been obtained with the model VI; they resulted statistically equal to the values obtained with almost all the other applied PTFs and were around $0.050 \mathrm{~m}^{3} \cdot \mathrm{m}^{-3}$ for the first three indicated textural classes and 0.016 $\mathrm{m}^{3} \cdot \mathrm{m}^{-3}$ for the Sandy soils.

At the Field Capacity, in Silty clay ( $\mathrm{SiC})$ and Silty loam (SiL) soils, the best soil moisture estimates have been obtained with the model II, with RMSD value of $0.053 \mathrm{~m}^{3} \cdot \mathrm{m}^{-3}$ not different from the ones obtained with the other PTFs.

For Silty clay loam (SiCL) and Loamy sandy (LSa), the more accurate soil moisture estimates have been obtained with the model V. However, even if the lowest RMSD value $\left(0.055 \mathrm{~m}^{3} \cdot \mathrm{m}^{-3}\right)$ was obtained, it was not statistically different from the other RMSD values observed with the other PTFs. As concern LSa soils, instead, the RMSD value recorded with the model V (0.017 $\left.\mathrm{m}^{3} \cdot \mathrm{m}^{-3}\right)$ is different from the ones obtained from the other compared PTFs (Table 6).

5.1.2 Soil moisture at the Wilting Point. For soils with different textural composition, the most accurate estimate of soil moistures at the wilting point has been obtained with the following PTFs (Table 7): for Clayey soils (C) with the model III that shows a RMSD value equal to $0.0425 \mathrm{~m}^{3} \cdot \mathrm{m}^{-3}$ and did not result statistically different from the value observed with model IV; for Silty clay (SiC), Clay loam (CL), Silty clay loam (SiCL), Sandy clay (SaC) and Sandy clay loam (SaCL), with the model IV, of which the RMSD values resulted equal to the ones obtained with the other applied PTFs; for Loamy (L) soils with the model II that shows RMSD index of $0.032 \mathrm{~m}^{3} \cdot \mathrm{m}^{-3}$, equal to the indexes of the other PTFs; for Silty loam (SiL) and Silty (Si) soils with model I, with RMSD values of 0.037 and $0.12 \mathrm{~m}^{3} \cdot \mathrm{m}^{-3}$, respectively, statistically different from the values recorded with other PTFs; for SaL, Sa and LSa with model V showing, for SaL and Sa soils, RMSD values equal to the ones obtained from other applied PTFs.

\subsection{Soil grouped on the basis of organic matter content}

5.2.1 Soil moisture at the Field Capacity. For the tendency clayey soils, the better soil moistures at the field capacity have been evaluated with: the model II with the organic matter content ranging from values lower than $1.2 \%$ to values included between 1.2 and $2.3 \%$; the model V, with organic matter content between 2.3 and 
Table 6. Values of root mean squared deviation (RMSD) index among soil moistures measured and estimated with the six PTFs at the Field Capacity within the soils grouped in USDA textural classes.

\begin{tabular}{|c|c|c|c|c|c|c|c|}
\hline \multicolumn{8}{|c|}{ Field Capacity } \\
\hline PTF & $\underset{\mathrm{m}^{3} \cdot \mathrm{m}^{-3}}{\text { RMSD }}$ & & ranking & PTF & $\begin{array}{c}\text { RMSD } \\
\mathrm{m}^{3} \cdot \mathrm{m}^{-3}\end{array}$ & & ranking \\
\hline \multicolumn{4}{|c|}{ Clayey soils (C) } & \multicolumn{4}{|c|}{ Sandy clay loam soils (SaCL) } \\
\hline Model I (Gupta \& Larson) & 0,087 & A & 1 & Model I & $\mathbf{0 , 0 3 7}$ & A & 1 \\
\hline Model II (Rawls et al.) & 0,089 & A & 2 & Model VI & 0,039 & $\mathrm{~B}$ & 2 \\
\hline Model IV(Rawls \& Brak.) & 0,094 & A & 3 & Model II & 0,043 & $\mathrm{~B}$ & 3 \\
\hline Model VI (Vereecken et al.) & 0,095 & A & 4 & Model IV & 0,056 & B & 4 \\
\hline Model III (De Jong et al.) & 0,106 & A & 5 & Model III & 0,059 & $\mathrm{~B}$ & 5 \\
\hline Model V (Saxton et al.) & 0,155 & A & 6 & Model V & 0,127 & B & 6 \\
\hline \multicolumn{4}{|c|}{ Silty clay soils $(\mathrm{SiC})$} & \multicolumn{4}{|c|}{ Silty loam soils (SiL) } \\
\hline Model II & $\mathbf{0 , 0 5 3}$ & A & 1 & Model II & $\mathbf{0 , 0 5 3}$ & A & 1 \\
\hline Model III & 0,060 & A & 2 & Model VI & 0,059 & A & 2 \\
\hline Model VI & 0,065 & A & 3 & Model IV & 0,0732 & $\mathrm{~B}$ & 3 \\
\hline Model I & 0,066 & A & 4 & Model I & 0,0734 & $\mathrm{~B}$ & 4 \\
\hline Model IV & 0,070 & A & 5 & Model V & 0,079 & $\mathrm{~B}$ & 5 \\
\hline Model V & 0,084 & A & 6 & Model III & 0,184 & $\mathrm{C}$ & 6 \\
\hline \multicolumn{4}{|c|}{ Sandy clay $(\mathrm{SaC})$} & \multicolumn{4}{|c|}{ Sandy loam soils (SaL) } \\
\hline Model VI & 0,050 & A & 1 & Model I & $\mathbf{0 , 0 4 3}$ & A & 1 \\
\hline Model I & 0,056 & A & 2 & Model II & 0,051 & A & 2 \\
\hline Model III & 0,059 & A & 3 & Model VI & 0,053 & A & 3 \\
\hline Model II & 0,061 & A & 4 & Model IV & 0,061 & $\mathrm{AB}$ & 4 \\
\hline Model IV & 0,065 & A & 5 & Model III & 0,076 & $\mathrm{~B}$ & 5 \\
\hline Model V & 0,150 & $\mathrm{~B}$ & 6 & Model V & 0,103 & $\mathrm{C}$ & 6 \\
\hline \multicolumn{4}{|c|}{ Loamy soils (L) } & \multicolumn{4}{|c|}{ Silty soils (Si) } \\
\hline Model VI & $\mathbf{0 , 0 5 0}$ & A & 1 & Model I & 0,14 & A & 1 \\
\hline Model II & 0,052 & A & 2 & Model V & 0,21 & $\mathrm{~B}$ & 2 \\
\hline Model I & 0,058 & $\mathrm{AB}$ & 3 & Model II & 0,25 & $\mathrm{C}$ & 3 \\
\hline Model IV & 0,068 & $\mathrm{~B}$ & 4 & Model VI & 0,26 & $\mathrm{D}$ & 4 \\
\hline Model V & 0,102 & $\mathrm{C}$ & 5 & Model IV & 0,27 & $\mathrm{D}$ & 5 \\
\hline Model III & 0,128 & $\mathrm{D}$ & 6 & Model III & 0,43 & $\mathrm{E}$ & 6 \\
\hline \multicolumn{4}{|c|}{ Clay loam soils (CL) } & \multicolumn{4}{|c|}{ Sandy soils (Sa) } \\
\hline Model VI & $\mathbf{0 , 0 5 3}$ & A & 1 & Model VI & 0,016 & A & 1 \\
\hline Model II & 0,055 & $\mathrm{AB}$ & 2 & Model V & 0,017 & A & 2 \\
\hline Model IV & 0,061 & $\mathrm{AB}$ & 3 & Model II & 0,048 & A & 3 \\
\hline Model I & 0,065 & $\mathrm{AB}$ & 4 & Model IV & 0,056 & A & 4 \\
\hline Model III & 0,074 & $\mathrm{BC}$ & 5 & Model III & 0,059 & A & 5 \\
\hline Model V & 0,094 & $\mathrm{C}$ & 6 & Model I & 0,071 & A & 6 \\
\hline \multicolumn{4}{|c|}{ Silty clay loam soils (SiCL) } & \multicolumn{4}{|c|}{ Loamy sand soils (LSa) } \\
\hline Model V & $\mathbf{0 , 0 5 5}$ & A & 1 & Model V & $\mathbf{0 , 0 1 7}$ & A & 1 \\
\hline Model VI & 0,063 & A & 2 & Model VI & 0,040 & $\mathrm{~B}$ & 2 \\
\hline Model II & 0,064 & A & 3 & Model IV & 0,043 & $\mathrm{~B}$ & 3 \\
\hline Model IV & 0,067 & A & 4 & Model III & 0,046 & $\mathrm{~B}$ & 4 \\
\hline Model I & 0,086 & A & 5 & Model II & 0,049 & $\mathrm{BC}$ & 5 \\
\hline Model III & 0,089 & A & 6 & Model I & 0,064 & $\mathrm{C}$ & 6 \\
\hline
\end{tabular}


Table 7. Values of root mean squared deviation (RMSD) index among soil moistures measured and estimated with the six PTFs at the Wilting Point within the soils grouped in USDA textural classes.

\begin{tabular}{|c|c|c|c|c|c|c|c|}
\hline \multicolumn{8}{|c|}{ Wilting Point } \\
\hline PTF & $\underset{\mathrm{m}^{3} \cdot \mathrm{m}^{-3}}{\text { RMSD }}$ & & ranking & PTF & $\begin{array}{l}\text { RMSD } \\
\mathrm{m}^{3} \cdot \mathrm{m}^{-3}\end{array}$ & & ranking \\
\hline \multicolumn{4}{|c|}{ Clayey soils (C) } & \multicolumn{4}{|c|}{ Sandy clay loam soils (SaCL) } \\
\hline Model III (De Jong el al.) & 0,0425 & A & $\mathbf{1}$ & Model IV & 0,017 & A & $\mathbf{1}$ \\
\hline Model IV (Rawls \& Brak.) & 0,0434 & A & 2 & Model V & 0,019 & A & 2 \\
\hline Model V (Saxton et al.) & 0,0649 & B & 3 & Model III & 0,021 & A & 3 \\
\hline Model II (Rawls et al.) & 0,0652 & B & 4 & Model VI & 0,031 & B & 4 \\
\hline Model VI (Vereecken et al.) & 0,080 & $\mathrm{C}$ & 5 & Model II & 0,035 & $\mathrm{~B}$ & 5 \\
\hline Model I (Gupta \& Larson) & 0,117 & $\mathrm{D}$ & 6 & Model I & 0,067 & $\mathrm{C}$ & 6 \\
\hline \multicolumn{4}{|c|}{ Silty clay soils $(\mathrm{SiC})$} & \multicolumn{4}{|c|}{ Silty loam soils (SiL) } \\
\hline Model IV & $\mathbf{0 , 0 3 8}$ & A & 1 & Model I & $\mathbf{0 , 0 3 7}$ & A & 1 \\
\hline Model III & 0,043 & A & 2 & Model II & 0,056 & $\mathrm{~B}$ & 2 \\
\hline Model V & 0,046 & A & 3 & Model VI & 0,062 & B & 3 \\
\hline Model II & 0,053 & A & 4 & Model IV & 0,068 & $\mathrm{C}$ & 4 \\
\hline Model VI & 0,073 & B & 5 & Model V & 0,082 & $\mathrm{D}$ & 5 \\
\hline Model I & 0,124 & $\mathrm{C}$ & 6 & Model III & 0,114 & $\mathrm{E}$ & 6 \\
\hline \multicolumn{4}{|c|}{ Sandy clay $(\mathrm{SaC})$} & \multicolumn{4}{|c|}{ Sandy loam soils (SaL) } \\
\hline Model IV & 0,016 & A & 1 & Model VI & $\mathbf{0 , 0 2 7}$ & A & 1 \\
\hline Model V & 0,017 & A & 2 & Model IV & 0,028 & A & 2 \\
\hline Model III & 0,018 & A & 3 & Model V & 0,029 & A & 3 \\
\hline Model II & 0,033 & A & 4 & Model III & 0,033 & A & 4 \\
\hline Model VI & 0,040 & A & 5 & Model II & 0,034 & A & 5 \\
\hline Model I & 0,075 & B & 6 & Model I & 0,047 & $\mathrm{~B}$ & 6 \\
\hline \multicolumn{4}{|c|}{ Loamy soils (L) } & \multicolumn{4}{|c|}{ Silty soils (Si) } \\
\hline Model II & $\mathbf{0 , 0 3 2}$ & A & $\mathbf{1}$ & Model I & 0,12 & A & 1 \\
\hline Model VI & 0,036 & $\mathrm{AB}$ & 2 & Model V & 0,20 & B & 2 \\
\hline Model IV & 0,041 & $\mathrm{AB}$ & 3 & Model IV & 0,21 & $\mathrm{C}$ & 3 \\
\hline Model V & 0,046 & $\mathrm{AB}$ & 4 & Model VI & 0,228 & $\mathrm{D}$ & 4 \\
\hline Model I & 0,051 & B & 5 & Model II & 0,229 & $\mathrm{D}$ & 5 \\
\hline Model III & 0,065 & $\mathrm{C}$ & 6 & Model III & 0,300 & $\mathrm{E}$ & 6 \\
\hline \multicolumn{4}{|c|}{ Clay loam soils (CL) } & \multicolumn{4}{|c|}{ Sandy soils $(\mathrm{Sa})$} \\
\hline Model IV & 0,036 & A & $\mathbf{1}$ & Model VI & 0,009 & A & $\mathbf{1}$ \\
\hline Model V & 0,038 & A & 2 & Model V & 0,018 & $\mathrm{AB}$ & 2 \\
\hline Model II & 0,044 & $\mathrm{AB}$ & 3 & Model II & 0,024 & $\mathrm{AB}$ & 3 \\
\hline Model VI & 0,048 & $\mathrm{AB}$ & 4 & Model IV & 0,029 & $\mathrm{AB}$ & 4 \\
\hline Model III & 0,058 & B & 5 & Model I & 0,031 & $\mathrm{AB}$ & 5 \\
\hline Model I & 0,084 & $\mathrm{C}$ & 6 & Model III & 0,035 & B & 6 \\
\hline \multicolumn{4}{|c|}{ Silty clay loam soils (SiCL) } & \multicolumn{4}{|c|}{ Loamy sand soils (LSa) } \\
\hline Model IV & 0,0407 & A & $\mathbf{1}$ & Model VI & 0,02 & A & $\mathbf{1}$ \\
\hline Model II & 0,0408 & A & 2 & Model IV & 0,0337 & $\mathrm{~B}$ & 2 \\
\hline Model VI & 0,043 & A & 3 & Model II & 0,03397 & B & 3 \\
\hline Model V & 0,048 & A & 4 & Model V & 0,03397 & $\mathrm{~B}$ & 4 \\
\hline Model III & 0,079 & B & 5 & Model III & 0,035 & B & 5 \\
\hline Model I & 0,082 & B & 6 & Model I & 0,051 & $\mathrm{C}$ & 6 \\
\hline
\end{tabular}


Table 8. Values of root mean squared deviation (RMSD) index among soil moistures measured and estimated with the six PTFs at the Field Capacity of the soils, grouped in classes of organic matter content within the three great textural groupings.

\begin{tabular}{|c|c|c|c|c|c|c|c|}
\hline \multicolumn{8}{|c|}{ Field Capacity } \\
\hline \multicolumn{8}{|c|}{ Tendency clayey soils } \\
\hline PTF & $\begin{array}{l}\text { RMSD } \\
\mathrm{m}^{3} \cdot \mathrm{m}^{-3}\end{array}$ & & ranking & PTF & $\begin{array}{l}\text { RMSD } \\
\mathrm{m}^{3} \cdot \mathrm{m}^{-3}\end{array}$ & & ranking \\
\hline \multicolumn{4}{|c|}{ O.M.: $<1,2 \%$} & \multicolumn{4}{|c|}{ O.M.:1,2-2,3 \% } \\
\hline Model II (Rawls et al.) & 0,08295 & A & 1 & Model II & $\mathbf{0 , 0 5 8}$ & A & 1 \\
\hline Model I (Gupta \& Larson) & 0,08299 & A & 2 & Model I & 0,067 & $\mathrm{AB}$ & 2 \\
\hline Model IV(Rawls \& Brak.) & 0,090 & A & 3 & Model IV & 0,069 & $\mathrm{AB}$ & 3 \\
\hline Model III (De Jong el al.) & 0,097 & A & 4 & Model III & 0,083 & $\mathrm{~B}$ & 4 \\
\hline Model VI (Vereecken et al.) & 0,104 & A & 5 & Model V & 0,084 & B & 5 \\
\hline Model V (Saxton et al.) & 0,158 & A & 6 & Model VI & 0,088 & $\mathrm{~B}$ & 6 \\
\hline \multicolumn{4}{|c|}{ O.M.: 2,3-3,0 \% } & \multicolumn{4}{|c|}{ O.M.: > 3,0 \% } \\
\hline Model V & $\mathbf{0 , 0 2 9}$ & A & 1 & Model V & $\mathbf{0 , 0 3 7}$ & A & $\mathbf{1}$ \\
\hline Model III & 0,0427 & $\mathrm{AB}$ & 2 & Model IV & 0,042 & A & 2 \\
\hline Model IV & 0,0431 & $\mathrm{AB}$ & 3 & Model VI & 0,051 & A & 3 \\
\hline Model II & 0,065 & $\mathrm{AB}$ & 4 & Model III & 0,056 & A & 4 \\
\hline Model VI & 0,076 & $\mathrm{AB}$ & 5 & Model II & 0,066 & A & 5 \\
\hline Model I & 0,098 & $\mathrm{~B}$ & 6 & Model I & 0,087 & A & 6 \\
\hline \multicolumn{8}{|c|}{ Loamy and tendency silty soils } \\
\hline \multicolumn{4}{|c|}{ O.M.: $<1,0 \%$} & \multicolumn{4}{|c|}{ O.M.: 1,0-1,9 \% } \\
\hline Model I & 0,057 & A & 1 & Model I & $\mathbf{0 , 0 5 2}$ & A & 1 \\
\hline Model II & 0,080 & A & 2 & Model II & 0,054 & A & 2 \\
\hline Model VI & 0,081 & A & 3 & Model IV & 0,075 & $\mathrm{AB}$ & 3 \\
\hline Model IV & 0,092 & $\mathrm{AB}$ & 4 & Model VI & 0,076 & B & 4 \\
\hline Model III & 0,138 & B & 5 & Model V & 0,103 & $\mathrm{C}$ & 5 \\
\hline Model V & 0,139 & $\mathrm{C}$ & 6 & Model III & 0,154 & $\mathrm{D}$ & 6 \\
\hline \multicolumn{4}{|c|}{ O.M.: 1,9-2,5\% } & \multicolumn{4}{|c|}{ O.M.: > 2,5 \% } \\
\hline Model II & $\overline{\mathbf{0 , 0 3 3}}$ & $\mathrm{A}$ & 1 & Model II & $\mathbf{0 , 0 5 0}$ & A & $\mathbf{1}$ \\
\hline Model VI & 0,054 & $\mathrm{AB}$ & 2 & Model IV & 0,057 & $\mathrm{AB}$ & 2 \\
\hline Model IV & 0,059 & B & 3 & Model VI & 0,061 & $\mathrm{AB}$ & 3 \\
\hline Model I & 0,061 & $\mathrm{~B}$ & 4 & Model V & 0,069 & $\mathrm{AB}$ & 4 \\
\hline Model V & 0,084 & $\mathrm{C}$ & 5 & Model I & 0,085 & B & 5 \\
\hline Model III & 0,149 & $\mathrm{D}$ & 6 & Model III & 0,156 & $\mathrm{C}$ & 6 \\
\hline \multicolumn{8}{|c|}{ Tendency sandy soils } \\
\hline \multicolumn{4}{|c|}{ O.M.: < 0,8 \% } & \multicolumn{4}{|c|}{ O.M.: 0,8-1,5 \% } \\
\hline Model I & 0,063 & $\mathrm{~A}$ & 1 & Model I & $\mathbf{0 , 0 3 5}$ & $\mathrm{A}$ & 1 \\
\hline Model II & 0,065 & A & 2 & Model II & 0,039 & A & 2 \\
\hline Model IV & 0,068 & A & 3 & Model IV & 0,046 & A & 3 \\
\hline Model III & 0,080 & A & 4 & Model III & 0,0639 & A & 4 \\
\hline Model V & 0,083 & A & 5 & Model VI & 0,0642 & A & 5 \\
\hline Model VI & 0,095 & A & 6 & Model V & 0,089 & $\mathrm{~B}$ & 6 \\
\hline \multicolumn{4}{|c|}{ O.M.: 1,5-2,0 \% } & \multicolumn{4}{|c|}{ O.M.: > 2,0 \% } \\
\hline Model IV & 0,026 & A & 1 & Model I & 0,046 & A & $\mathbf{1}$ \\
\hline Model III & 0,031 & A & 2 & Model II & 0,051 & A & 2 \\
\hline Model II & 0,034 & A & 3 & Model IV & 0,076 & A & 3 \\
\hline Model I & 0,038 & A & 4 & Model III & 0,088 & $\mathrm{AB}$ & 4 \\
\hline Model V & 0,076 & A & 5 & Model VI & 0,110 & $\mathrm{AB}$ & 5 \\
\hline Model VI & 0,089 & A & 6 & Model V & 0,125 & $\mathrm{~B}$ & 6 \\
\hline
\end{tabular}


Table 9. Values of root mean squared deviation (RMSD) index among soil moistures measured and estimated with the six PTFs at the Wilting Point of the soils, grouped in classes of organic matter content within the three great textural groupings.

\begin{tabular}{|c|c|c|c|c|c|c|c|}
\hline \multicolumn{8}{|c|}{ Wilting Point } \\
\hline \multicolumn{8}{|c|}{ Tendency clayey soils } \\
\hline PTF & $\begin{array}{l}\text { RMSD } \\
\mathrm{m}^{3} \cdot \mathrm{m}^{-3}\end{array}$ & & ranking & PTF & $\begin{array}{c}\text { RMSD } \\
\mathrm{m}^{3} \cdot \mathrm{m}^{-3}\end{array}$ & & ranking \\
\hline \multicolumn{2}{|l|}{ O.M.: < 1,2 \% } & & & \multicolumn{2}{|c|}{ O.M.: 1,2-2,3 \% } & & \\
\hline Model IV(Rawls \& Brak.) & 0,046 & A & 1 & Model IV & $\mathbf{0 , 0 3 9}$ & A & 1 \\
\hline Model II (Rawls et al.) & 0,053 & A & 2 & Model V & 0,046 & $\mathrm{AB}$ & 2 \\
\hline Model III (De Jong el al.) & 0,058 & A & 3 & Model II & 0,053 & $\mathrm{ABC}$ & 3 \\
\hline Model V (Saxton et al.) & 0,063 & A & 4 & Model III & 0,056 & $\mathrm{BC}$ & 4 \\
\hline Model I (Gupta \& Larson) & 0,105 & $\mathrm{~B}$ & 5 & Model VI & 0,071 & $\mathrm{C}$ & 5 \\
\hline Model VI (Vereecken et al.) & 0,117 & $\mathrm{~B}$ & 6 & Model I & 0,102 & $\mathrm{D}$ & 6 \\
\hline \multicolumn{4}{|c|}{ O.M.: 2,3-3,0 \% } & \multicolumn{4}{|c|}{ O.M.: > 3,0 \% } \\
\hline Model IV & 0,014 & A & 1 & Model IV & 0,012 & A & $\mathbf{1}$ \\
\hline Model V & 0,023 & A & 2 & Model V & 0,021 & A & 2 \\
\hline Model III & 0,042 & A & 3 & Model VI & 0,039 & A & 3 \\
\hline Model II & 0,047 & A & 4 & Model II & 0,0436 & A & 4 \\
\hline Model VI & 0,049 & A & 5 & Model III & 0,0444 & A & 5 \\
\hline Model I & 0,092 & B & 6 & Model I & 0,087 & $\mathrm{~B}$ & 6 \\
\hline \multicolumn{8}{|c|}{ Loamy and tendency silty soils } \\
\hline \multicolumn{4}{|c|}{ O.M.: $<1,0 \%$} & \multicolumn{4}{|c|}{ O.M.: 1,0-1,9 \% } \\
\hline Model V & $\mathbf{0 , 0 5 0}$ & A & $\mathbf{1}$ & Model II & $\mathbf{0 , 0 5 0}$ & A & $\mathbf{1}$ \\
\hline Model IV & 0,051 & A & 2 & Model VI & 0,051 & A & 2 \\
\hline Model II & 0,056 & A & 3 & Model I & 0,052 & A & 3 \\
\hline Model VI & 0,062 & $\mathrm{AB}$ & 4 & Model IV & 0,053 & A & 4 \\
\hline Model I & 0,068 & $\mathrm{AB}$ & 5 & Model V & 0,063 & A & 5 \\
\hline Model III & 0,075 & $\mathrm{~B}$ & 6 & Model III & 0,091 & $\mathrm{~B}$ & 6 \\
\hline \multicolumn{4}{|c|}{ O.M.: 1,9-2,5 \% } & \multicolumn{4}{|c|}{ O.M.: > 2,5 \% } \\
\hline Model I & $\mathbf{0 , 0 3 7}$ & A & 1 & Model I & 0,04317 & A & 1 \\
\hline Model II & 0,042 & $\mathrm{AB}$ & 2 & Model II & 0,04321 & A & 2 \\
\hline Model IV & 0,054 & $\mathrm{BC}$ & 3 & Model VI & 0,049 & A & 3 \\
\hline Model VI & 0,057 & $\mathrm{BC}$ & 4 & Model IV & 0,059 & $\mathrm{AB}$ & 4 \\
\hline Model V & 0,065 & $\mathrm{C}$ & 5 & Model V & 0,071 & $\mathrm{~B}$ & 5 \\
\hline Model III & 0,092 & $\mathrm{D}$ & 6 & Model III & 0,091 & $\mathrm{C}$ & 6 \\
\hline \multicolumn{8}{|c|}{ Tendency sandy soils } \\
\hline \multicolumn{4}{|c|}{ O.M.: < 0,8 \% } & \multicolumn{4}{|c|}{ O.M.: 0,8-1,5 \% } \\
\hline Model V & $\mathbf{0 , 0 2 9 5}$ & $\mathrm{A}$ & 1 & Model IV & 0,025 & A & 1 \\
\hline Model IV & 0,0299 & A & 2 & Model V & 0,026 & A & 2 \\
\hline Model II & 0,031 & A & 3 & Model VI & 0,0323 & A & 3 \\
\hline Model III & 0,035 & A & 4 & Model III & 0,0328 & A & 4 \\
\hline Model VI & 0,042 & A & 5 & Model II & 0,0331 & A & 5 \\
\hline Model I & 0,048 & A & 6 & Model I & 0,050 & $\mathrm{~B}$ & 6 \\
\hline \multicolumn{4}{|c|}{ O.M.: 1,5-2,0 \% } & \multicolumn{4}{|c|}{ O.M.: > 2,0 \% } \\
\hline Model IV & 0,017 & $\mathrm{~A}$ & $\mathbf{1}$ & Model I & $\mathbf{0 , 0 3 0}$ & A & 1 \\
\hline Model V & 0,021 & A & 2 & Model II & 0,036 & A & 2 \\
\hline Model III & 0,027 & $\mathrm{AB}$ & 3 & Model III & 0,037 & A & 3 \\
\hline Model II & 0,038 & $\mathrm{AB}$ & 4 & Model V & 0,038 & A & 4 \\
\hline Model VI & 0,041 & $\mathrm{AB}$ & 5 & Model IV & 0,040 & A & 5 \\
\hline Model I & 0,051 & B & 6 & Model VI & 0,044 & A & 6 \\
\hline
\end{tabular}


Table 10. Correlation coefficients between input parameters and the differences among estimated and measured soil moistures $(\Delta \theta)$ regarding the PTFs and soil groupings where they produce the best performance at the field capacity.

\section{Field Capacity}

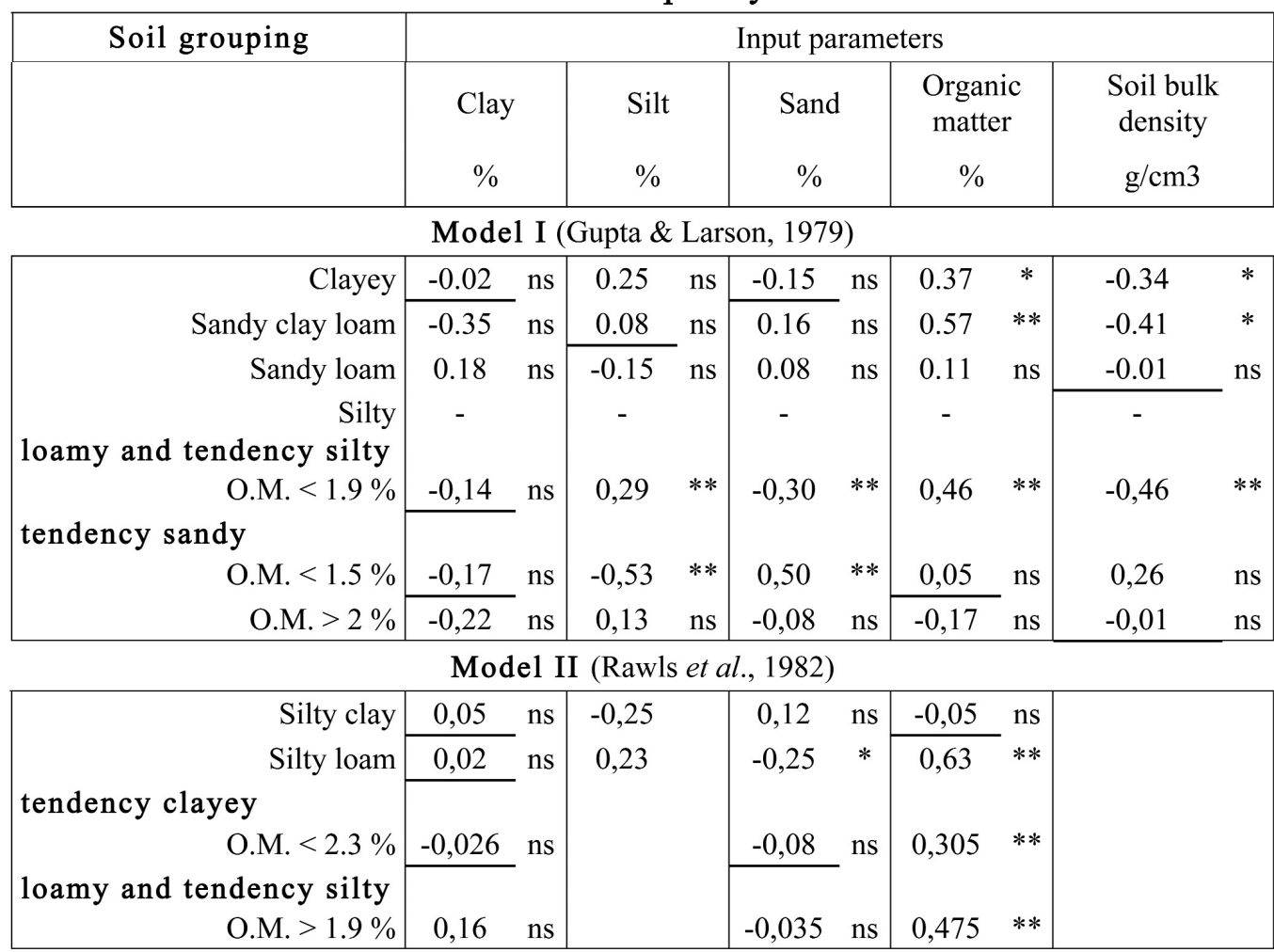

Model IV (Rawls \& Brakensiek, 1985)

\begin{tabular}{|c|c|c|c|c|c|c|c|c|}
\hline $\begin{array}{r}\text { tendency sandy } \\
\text { O.M. } 1.5-2 \%\end{array}$ & $-0,43$ & $\mathrm{~ns}$ & 0,75 & ns & & & 0,61 & ns \\
\hline \multicolumn{9}{|c|}{ Model V (Saxton et al., 1986) } \\
\hline Silty clay loam & $-0,08$ & $\mathrm{~ns}$ & 0,11 & $\mathrm{~ns}$ & & & & \\
\hline Loamy sand & 0,47 & ns & 0,48 & ns & & & & \\
\hline tendency clayey & & & & & & & & \\
\hline O.M. $>2.3 \%$ & $-0,58$ & * & $-0,29$ & ns & & & & \\
\hline \multicolumn{9}{|c|}{ Model VI (Vereecken et al., 1989) } \\
\hline Sandy clay & $-0,17$ & $\mathrm{~ns}$ & $-0,21$ & ns & 0,65 & & $-0,50$ & ns \\
\hline Loamy & 0,32 & $* *$ & $-0,18$ & ns & 0,30 & $*$ & $-0,22$ & ns \\
\hline Clay loam & $-0,15$ & ns & 0,00 & ns & 0,45 & $* *$ & $-0,22$ & ns \\
\hline Sandy & - & & - & & - & & - & \\
\hline
\end{tabular}

$3.0 \%$ and greater than $3.0 \%$. With the lowest and the highest organic matter contents, the RMSD values varied between 0.083 and $0.058 \mathrm{~m}^{3} \cdot \mathrm{m}^{-3}$ with the model II and between 0.029 and $0.037 \mathrm{~m}^{3} \cdot \mathrm{m}^{-3}$ with model $\mathrm{V}$, respectively. However, these values are not different from the ones obtained with the most applied PTFs (Tab. 8).
In relation to loamy and tendency silty soils, the lowest difference values between soil moisture estimated and measured have been obtained: with the model I when the organic matter content is lower than $1.0 \%$ and is included between 1.0 and $1.9 \%$; with the model II, when the organic matter content varies between 1.9 
Table 11. Correlation coefficients between input parameters and the differences among estimated and measured soil moistures $(\Delta \theta)$ regarding the PTFs and soil groupings where they produce the best performance at the wilting point.

Wilting Point

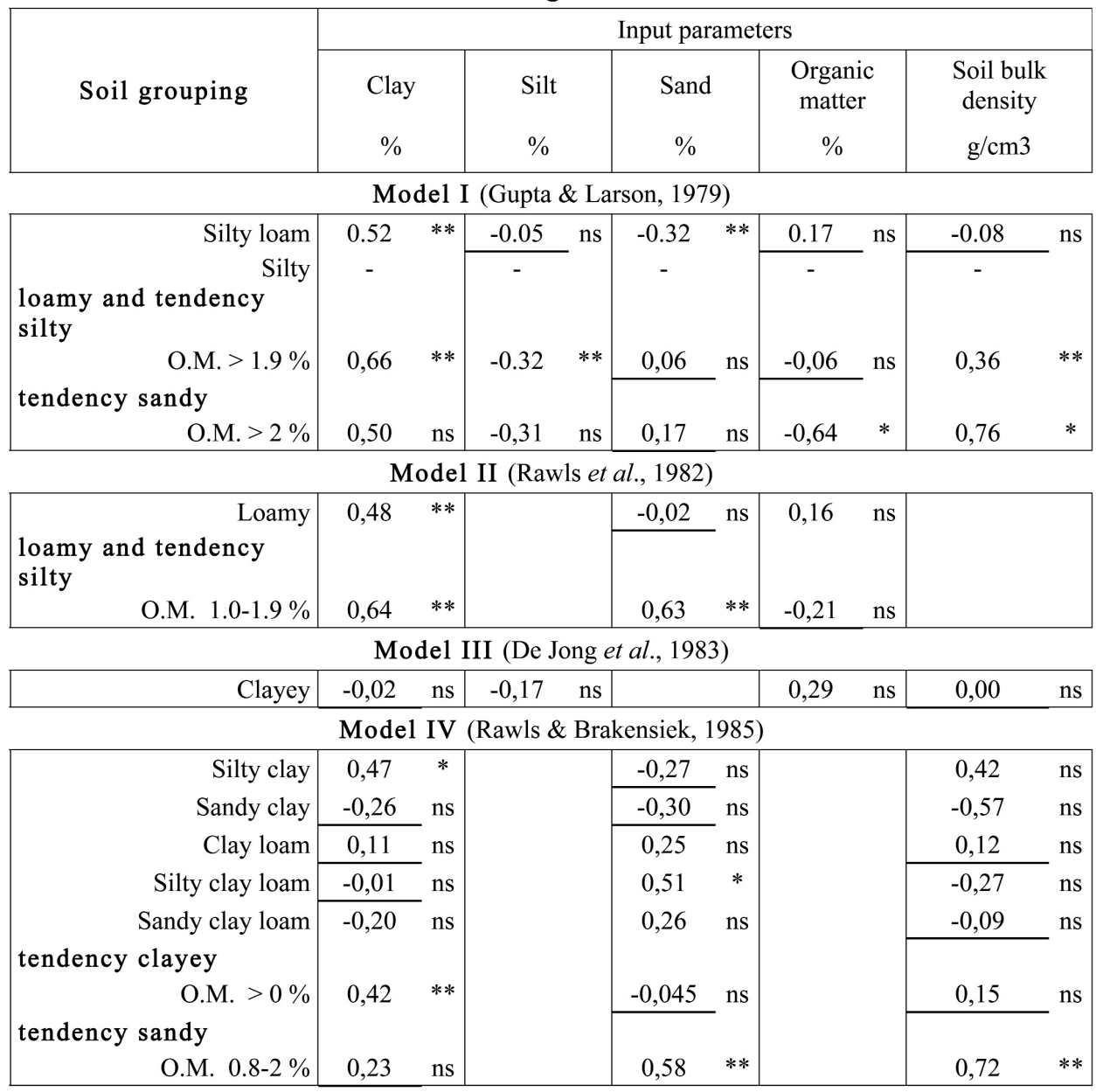

Model V (Saxton et al., 1986)

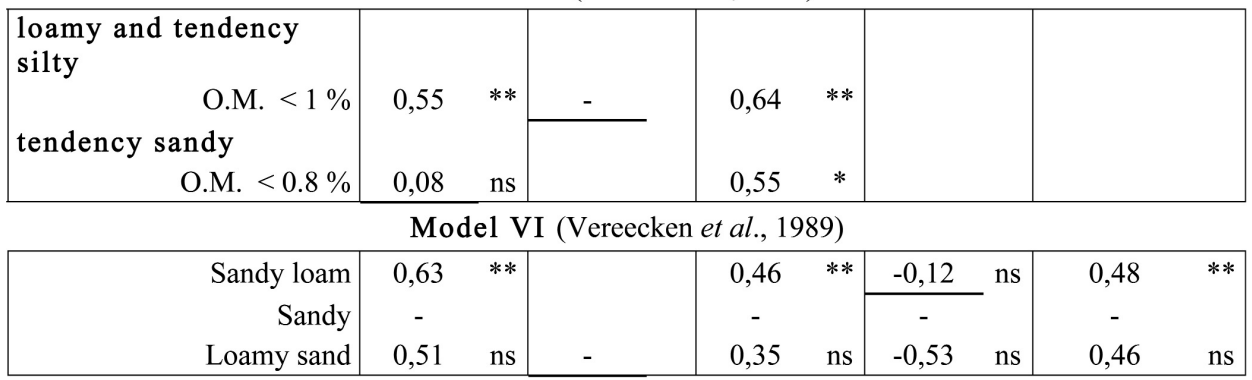

and $2.5 \%$ and is greater than $2.5 \%$. Also in these soil types the RMSD values calculated with the suggested PTFs are not different from RMSD values calculated with the others (Tab. 8).

For tendency sandy soils, the most accurate of the estimate of soil moisture at field capacity has been obtained with the model I in soils with organic matter content lower than $0.8 \%$, between 0.8 and $1.5 \%$ and higher than $2.0 \%$; with the model IV in soils having organic matter content between 1.5 and $2.0 \%$.

In any case the RMSD index values are not statistically different from those obtained with the other applied PTFs (Tab. 8). 
5.2.2 Soil moisture at the Wilting Point. At the wilting point, for the tendency clayey soils with whatever organic matter content, soil moisture has been estimated with reasonable approximation with the most applied PTFs; however, applying model IV the RMSD values obtained have been the lowest, varying from 0.046 to $0.039,0.014$ and $0.012 \mathrm{~m}^{3} \cdot \mathrm{m}^{-3}$, for soils with organic matter content lower than $1.2 \%$, between 1.2 and $2.3 \%$, between 2.3 and $3.0 \%$ and higher than $3.0 \%$, respectively (Tab. 9).

For loamy and tendency silty soils, the most accurate soil moisture estimates at the wilting point have been obtained with : models V, II and $\mathrm{I}$ in soils with organic matter content lower than $1.0 \%$, between 1.0 e $1.9 \%$ and higher than $1.9 \%$, respectively. Applying these models, the RMSD values vary from 0.050 to 0.037 $\mathrm{m}^{3} \cdot \mathrm{m}^{-3}$ and are not always different from those obtained with other applied PTFs (Tab. 9).

For tendency sandy soils, the lowest RMSD values have been observed applying the models $\mathrm{V}, \mathrm{IV}$ and I when the soil organic matter content was lower than $0.8 \%$, between 0.8 and $2.0 \%$ and higher than $2.0 \%$, respectively (table 9); these RMSD values were not statistically different from the values obtained with the most of the applied PTFs.

Comparing soil moistures measured in laboratory and estimated with the six pedotransfer functions (PTFs), it appears that the most careful evaluations have been obtained with different PTFs in relation to the textural classes, organic matter content and the matric potential considered (FC or WP).

In Tables 10 and 11, the correlation coefficients (those underlined affect less the statistical errors) among the input parameters and the differences among soil moistures estimated and determined in laboratory $(\Delta \varnothing)$, regarding the PTFs and soil grouping wherein they provide the best performances at the FC and the WP, respectively, are reported.

\section{Conclusions}

In conclusion, considering these results, in Apulian soils grouped on a basis of the textural composition and organic matter content, it is possible to suggest the PTFs that provide the estimated soil moistures values almost equal to the measured ones at the Field Capacity and the Wilting Point.

A) For soil moisture at the field capacity:

1) model I (Gupta and Larson, 1979) in Clayey, Sandy clay loam, Sandy loam and Silty soil, in loamy and tendency silty soils with O.M. content less than $1.9 \%$ and in tendency sandy soils with O.M. content less than $1.5 \%$ and greater than $2 \%$;

2) model II (Rawls et al., 1982) in Silty clay and Silty loam soils, in tendency clayey soils with O.M. less than $2.3 \%$ and in loamy and tendency silty soils with O.M. greater than $1.9 \%$;

3) model IV (Rawls and Brakensiek, 1985) in tendency sandy soils with O.M. content between 1.5 and $2 \%$;

4) model V (Saxton et al., 1986) in Silty clay loam, Loamy sand soils and in tendency clayey soils with O.M. content greater than $2.3 \%$;

5) model VI (Vereecken et al., 1989) in Sandy clay, Loamy, Clay loam and Sandy soils.

B) For soil moisture at the wilting point:

1) model I (Gupta and Larson, 1979) in Silty loam, Silty soils and in general in loamy and tendency silty and in tendency sandy soils with O.M. content greater than $1.9 \%$ and than $2 \%$, respectively;

2) model II (Rawls et al., 1982) in Loamy soils and in loamy and tendency silty soils with O.M. between 1.0 and $1.9 \%$;

3) model III (De Jong et al., 1983) in Clayey soils;

4) model IV (Rawls and Brakensiek, 1985) in Silty clay, Sandy clay, Clay loam, Silty clay loam, Sandy clay loam soils and generally in tendency clayey soils with whatever O.M. content and in tendency sandy soils with O.M. content between 0.8 and $2 \%$;

5) model V (Saxton et al., 1986) in loamy and tendency silty soils with O.M. content less than $1 \%$ and in tendency sandy soils with O.M. less than $0.8 \%$;

6) model VI (Vereecken et al., 1989) in Sandy loam, Sandy and Loamy sand soils.

\section{References}

Adams W.A. 1973. The effect of organic matter on the bulk and true densities of some uncultivated podzoilc soils. J. Soil Sci., 24:10-17.

Alexander E.B. 1980. Bulk densities of California soils 
in relation to other soil properties. Soil Sci. Soc. Am. J., 44:689-692.

Buccigrossi F., Caliandro A., Rubino P., Mastro A.M. 2009. Testing some Pedo-transfer functions (PTFs) in Apulia Region. Riv Ing. Agr., in press.

Cornelis W.M., Ronsyn J., Meirvenne M. Van, Hartmann R. 2001. Evaluation of Pedotransfer functions for predicting the soil moisture retention curve. Soil Sci. Soc. Am. J., 65:638-648.

Curtis R.O., Post B.W. 1964. Estimating bulk density from organic-matter content in some Vermont forest soils. Soil Sci. Soc. Am. Proc., 28:285-286.

Davis J.C. 1973. Statistical and data analysis in geology., Wiley, New York. In Rawls 1982.

De Jong R., Campbell C.A., Nicolaichuk W. 1983. Water retention equations and their relationship to soil organic matter and particle size distribution for disturbed samples. Can. J. Soil Sci., 63:291-302.

Gupta S.C., Larson W.E. 1979a. A model for predicting packing density of soils using particle-size distribution. Soil Sci. Soc. Am. J., 43:758-764.

Gupta S.C., Larson W.E. 1979 b. Estimating soil water retention characteristics from particle size distribution, organic matter content, and bulk density. Water Resour. Res., 15:1633-1635.

Jamison V.C., Kroth E.M. 1958. Available moisture storage capacity in relation to textural composition and organic matter content of several Missouri soils. Soil Sci. Soc. Am. Proc., 22:189-192.

Heinonen R. 1977. Towards "normal" soil bulk density. Soil Sci. Soc. Am. J., 41:1214-1215.

Kobayashi K., Salam M.U. 2000. Comparing simulated and measured values using mean squared deviation and its components. Agron. J., 92:345-362.

Leonavičiutė N. 2000. Predicting soil bulk and particle densities by Pedotransfer Functions from existing soil data in Lithuania. Geografijos metraštis, $33 \mathrm{t}$.

Petersen G.W., Cunningham R.L., Matelski R.P. 1968. Moisture characteristics of Pennsylvania soils: II. Soil factors affecting moisture retention within a textural class-silt loam. Soil Sci. Soc. Amer. Proc., 32:866870.

Prebble R.E., Stirk G.B. 1959. Effect of free iron oxide on range of available water in soils. Soil Sci., 88:213217.

Rawls W.J. 1982. Estimating soil bulk density from particle size analysis and organic matter content. Soil Sci., 135, 2:123-125.

Rawls W.J., Brakensiek D.L. 1985. Prediction of soil water properties for hydrological modelling. In: Ungaro and Calzolari, 2001.

Rawls W.J., Brakensiek D.L. 1989. Estimation of soil water retention and hydraulic properties. In: H.J. MorelSeytoux (ed.): Unsaturated Flow in Hydrologic Modeling, Theory and Practice, 275-300.
Rawls W.J., Brakensiek D.L., Saxton K.E. 1982. Estimation of soil water properties. Trans. ASAE, 25:13161320. In: Saxton et al., 1986.

Rawls W.J., Gish T.J., Brakensiek D.L. 1991. Estimating soil water retention from soil physical properties and characteristics. Adv. Soil Sci., 16:213-234.

Richards L.A. 1949. Methods of measuring soil moisture tension. Soil Sci., 68:95-112.

Richards L.A., Weaver L.R. 1947. Pressure-membrane apparatus-construction and use. Agr. Eng., 28:451454.

Romano N., Palladino M. 2002. Prediction of soil water retention using soil physical data and terrain attributes. J. Hydrol., 265:56-75.

Saini G.R. 1966. Organic matter as a measure of bulk density of soil. Nature, 210:1295-1296. In: Alexander, 1980.

Salter P.J., Williams J.B. 1965a. The influence of texture on the moisture characteristics of soils. I. A critical comparison of techniques for determining the available-water capacity and moisture characteristic curve of a soil. J. Soil Sci., 16:1-15.

Salter P.J., Williams J.B. 1965b. The influence of texture on the moisture characteristics of soils. II. Availablewater capacity and moisture release characteristics. J. Soil Sci., 16:310-317.

Saxton K.E., Rawls W.J., Romberger J.S., Papendick R.I. 1986. Estimating generalized soil-water characteristics from texture. Soil Sci. Soc. Am. J., 50:1031-1036.

Sequi P., De Nobili M. 2000. "Carbonio Organico" in Metodi di Analisi Chimica del Suolo. Ministero delle Politiche Agricole e Forestali, Osservatorio Nazionale Pedologico e per la Qualità del Suolo, Franco Angeli, VII:1-16.

Tietie O., Tapkenhinrichs M. 1993. Evaluation of PedoTransfer Function. Soil Sci. Soc. Am. J., 57:1088-1095.

Ungaro F., Calzolari C. 2001. Using existing soil databases for estimating retention properties for soils of the Pianura Padano-Veneta region of North Italy. Geoderma, 99:99-121.

United States Department of Agriculture (USDA), 1951. Soil Survey Manual USDA. Handbook, 18:205223.

Vereecken H., Maes J., Feyen J., Darius P. 1989. Estimating the soil moinsture retention characteristic from texture, bulk density, and carbon content. Soil Sci., 148:389-403.

Wösten J.H.M., Pachepsky Ya.A., Rawls W.J. 2001. Pedotransfer functions: bridging the gap between available basic soil data and missing soil hydraulic characteristics. J. Hydrol., 251:123-150.

Wösten J.H.M., van Genuchten M.T. 1988. Using texture and other soil properties to predict the unsaturated soil hydraulic functions. Soil Sci. Soc. Am. J., 52:1762-1770. 
